\title{
HUBUNGAN RIWAYAT KONTAK PENDERITA TUBERKULOSIS PARU (TB) DENGAN KEJADIAN TB PARU ANAK DI BALAI PENGOBATAN PENYAKIT PARU-PARU (BP4) PURWOKERTO
}

\author{
Yulistyaningrum dan Dwi Sarwani Sri Rejeki \\ Fakultas Kesehatan Masyarakat, Universitas Ahmad Dahlan, Yogyakarta
}

\begin{abstract}
Background: Tuberculosis (TB) is chronic communicable disease that caused byMycobacterium tuberculosis. Nowadays, TB still becomes an important health problem. In Indonesia, every year there are 1,3 million children under 15 years old have infected M. tuberculosis and 450.000 children died because of TB. Based on the age-based diagnose report, a percentage of TB patients on child group (0-14 years old) in year 2009 at BP4 Purwokerto was equal $26,42 \%$. This condition was probably happened due to any contact inside a house with adult TB sufferers. The objective of this research is to find out the association between the contact history of TB and the occurrence of pulmonary TB on a child group at BP4 Purwokerto.

Method : This was an observational analytic research with cases control approach. The numbers of samples are 76 children divided into 38 cases and 38 controls. Cases were children patients who were 0-14 years old, clinically diagnosed as TB sufferer and confirmed by the result of $x$-ray test that showed sugestif description at BP4 Purwokerto. Controls were children patients who were 0-14 years old, clinically diagnosed as not TB sufferer and confirmed by the result of $x$-ray test that not showed sugestif description at BP4 Purwokerto. Data were analyzed by using the methods of univariate, bivariate (Chi-Square test and Mantel Haenszel test).

Result : The result of this research showed that the contact history of TB had a significant association with the occurrence of pulmonary TB on child group at BP4 Purwokerto without influenced by economic status, BCG scar status and availability of smoker inside a house $(P=$ $0,001 ; \mathrm{OR}=6,378 ; 95 \% \mathrm{Cl} 2,151-18,918)$. To prevent the occurrence of pulmonary TB on a child, parents should keep away their children from direct contact with adult TB sufferers trough separating them temporarilly.
\end{abstract}

Keywords : History of contact TB, Pulmonary TB on child Bibliography : 76 (1961-2010)

\section{PENDAHULUAN}

Tuberkulosis (TB) merupakan penyakit menular kronis yang disebabkan oleh kuman Mycobacterium tuberculosis. Sampai saat ini TB merupakan masalah kesehatan masyarakat yang penting ${ }^{1}$. Estimasi incidence rate pada tahun 2003 , TB di Indonesia berdasarkan pemeriksaan sputum BTA (+) adalah 128 per 100.000 penduduk. Sedangkan untuk tahun yang sama, estimasi TB semua kasus (prevalence rate) adalah 675 per 100.000 penduduk $^{2}$. Di Indonesia setiap tahun ada 1,3 juta anak berumur kurang dari 15 tahun terinfeksi kuman TB dan setiap tahun ada 450.000 kematian anak akibat penyakit ini ${ }^{3}$. Menurut Samallo dalam FKUI ${ }^{4}$, usia anak merupakan usia yang sangat rawan terhadap penularan penyakit TB terutama tuberkulosis (TB) paru. Sebesar $74,23 \%$ dari seluruh kasus tuberkulosis terdapat pada golongan anak, dimana angka penularan dan bahaya penularan yang tinggi terdapat pada golongan umur 0-6 tahun dan golongan umur 7-14 tahun. Faktor risiko yang dapat menimbulkan penyakit tuberkulosis terutama pada anak-anak adalah faktor genetik, malnutrisi, vaksinasi, kemiskinan dan kepadatan penduduk ${ }^{5}$ Faktor risiko utama yang dapat menimbulkan penyakit TB paru pada anak adalah kontak dengan penderita TB dewasa. Anak-anak yang sakit TB tidak dapat menularkan kuman TB ke anak lain atau ke orang dewasa. Sebab, pada anak biasanya TB bersifat tertutup 5 . Kasus TB paru anak di Balai Pengobatan Penyakit Paru-Paru pada tahun 2009 
mencapai $26,4 \%$. Hal ini dimungkinkan karena adanya kontak serumah atau sering berinteraksi dengan orang dewasa yang terbukti mengidap TB paru dengan hasil tes Basil Tahan Asam (BTA) positif.

\section{METODE PENELITIAN}

Penelitian ini menggunakan metode survei analitik dengan pendekatan Case Control Study. Penelitian dilakukan di Balai Pengobatan Penyakit Paru-Paru (BP4) Purwokerto dengan sampel penelitian berjumlah 76 orang yaitu 38 sampel kasus dan 38 sampel kontrol. Sampel dalam penelitian ini adalah data primer yaitu data yang diperoleh dari hasil wawancara kepada responden dengan menggunakan kuesioner dan data sekunder yaitu rekam medik hasil foto rontgen paru pasien anak dan profil tempat penelitian (BP4 Purwokerto).

\section{HASIL PENELITIAN DAN PEMBAHASAN}

a. Hubungan Riwayat Kontak TB dengan Kejadian TB Paru Anak di BP4 Purwokerto Berdasarkan hasil analisis bivariat dengan uji Chi-Square menunjukkan hasil $p=0,001$, maka secara statistik dapat dikatakan bahwa ada hubungan yang bermakna antara riwayat kontak tuberkulosis (TB) dengan kejadian TB paru anak. Berdasarkan hasil analisis berstrata dengan uji Mantel Haenszel, diketahui hasil bahwa secara statistik hubungan riwayat kontak TB dengan kejadian TB paru anak di BP4 Purwokerto memiliki nilai OR riwayat kontak yang sesungguhnya adalah sebesar 6,378 dengan $\mathrm{Cl}$ 95\% (2,151-18,918), dari hasil tersebut dapat disimpulkan bahwa odds pada kelompok anak yang menderita tuberkulosis (TB) paru (kelompok kasus) 6,378 kali lebih besar dibanding odds pada kelompok anak yang tidak menderita TB paru (kelompok kontrol) untuk adanya riwayat kontak TB. Hasil ini sesuai dengan penelitian Dudeng $\mathrm{dkk}^{6}$, yang menyatakan bahwa anak yang pernah kontak dengan orang dewasa yang menderita TB BTA (+) atau suspek yang diduga menjadi sumber penular mempunyai risiko 3,91 kali lebih besar menderita $\mathrm{TB}$, dibandingkan dengan anak yang tidak mempunyai riwayat kontak. Anak-anak yang tinggal di rumah dimana terdapat orang dewasa yang mengidap TB aktif atau yang memiliki risiko TB, akan memiliki risiko sama tingginya untuk mengidap TB. Menurut Rosmayudi ${ }^{7}$, sumber penularan yang paling berbahaya adalah penderita TB dewasa dan orang dewasa yang menderita TB paru dengan kavitas (lubang pada paru-paru). Kasus seperti ini sangat infeksius dan dapat menularkan penyakit melalui batuk, bersin dan percakapan. Semakin sering dan lama kontak, makin besar pula kemungkinan terjadi penularan. Sumber penularan bagi bayi dan anak yang disebut kontak erat adalah orangtuanya, orang serumah atau orang yang sering berkunjung dan sering berinteraksi langsung.

b. Hubungan antara Variabel Perancu (Status Ekonomi, Status Imunisasi BCG dan Keberadaan Perokok di Dalam Rumah) dengan Variabel Bebas (Riwayat Kontak TB) dan Variabel Terikat (Kejadian TB Paru Anak)

1) Status Ekonomi

Berdasarkan hasil penelitian menunjukkan bahwa status ekonomi bukan merupakan variabel perancu. Hasil analisis dengan uji Chi-Square menunjukkan nilai $p=1,000$. Hal ini menunjukkan bahwa tidak adahubungan antara status ekonomi dengan kejadian TB paru anak sehingga tidak masuk dalam kandidat perancu. Hasil penelitian ini tidak sesuai dengan hasil penelitian ${ }^{8}$, yang 
menunjukkan bahwa ada hubungan antara status ekonomi keluarga dengan kejadian TB pada balita di Kabupaten Kuantan Singingi, Riau ( $p=0,0012$ \& $\mathrm{OR}=2,587$ ). Status ekonomi seharusnya mempunyai kontribusi besar terhadap kejadian TB paru pada anak. Tingkat pendapatan yang rendah atau kemiskinan mengarah pada perumahan yang terlampau padat. Keadaan padatnya hunian ini meningkatkan risiko penularan TB khususnya pada anak-anak yang rentan terhadap paparan $M$. tuberculosis karena lebih memudahkan terjadinya interaksi secara langsung antara penderita TB dengan orang yang sehat lainnya khususnya anak-anak ${ }^{9}$.

2 Status Imunisasi BCG

Hasil penelitian menunjukkan bahwa status imunisasi BCG bukan merupakan variabel perancu. Hasil analisis dengan uji Chi-Square menunjukkan nilai konstan. Hal ini menunjukkan bahwa tidak ada hubungan antara status imunisasi BCG dengan kejadian TB paru anak sehingga tidak masuk dalam kandidat perancu. Hasil penelitian ini tidak sesuai dengan hasil penelitian Murniasih dan Livana (2007) yang menunjukkan bahwa ada hubungan yang bermakna antara pemberian imunisasi BCG dengan kejadian TB paru anak di BP4 Ambarawa dengan nilai $p$ sebesar 0,048. Murniasih dan Livana ${ }^{10}$, menyatakan bahwa anak yang telah diberikan imunisasi BCG (ada jaringan parut atau scar pada lengan kanan) dan ternyata menderita TB Paru besar kemungkinan karena anak telah terinfeksi kuman Tuberkulosis sebelum diberikan imunisasi BCG.

\section{Keberadaan Perokok di Dalam Rumah}

Berdasarkan hasil penelitian menunjukkan bahwa setelah dilakukan analisis berstrata dengan uji Mantel Haenszel, variabel keberadaan perokok bukan merupakan variabel perancu (Crude OR $\leq(5,963) \leq$ adjusted OR $(6,378)$ \& $p(0,001) \leq 0,05)$. Hal ini tidak sesuai denganpenelitian Wibowo ${ }^{11}$, pada penelitian kasus kontak TB paru di Poliklinik RSUP Manado, menyimpulkan bahwa anak yang tinggal pada keluarga yang mempunyai kebiasaan merokok dan terdapat kontak langsung dengan penderita TB dewasa mempunyai risiko 4 kali lebih besar menderita TB. ${ }^{12}$, menyatakan bahwa absorpsi asap rokok oleh para perokok pasif dipengaruhi oleh jumlah produksi asap rokok, dalamnya isapan dari perokok, ada tidaknya ventilasi untuk penyebaran dan pergerakan asap, jarak antara perokok dan bukan perokok dan lamanya paparan.

\section{SIMPULAN DAN SARAN}

\section{a. Simpulan}

1) Sebagian besar kelompok kasus ada riwayat kontak dengan penderita TB dewasa BTA positif sebanyak 28 orang $(73,7 \%)$, sedangkan pada kelompok kontrol sebagian besar tidak ada riwayat kontak dengan penderita TB dewasaBTA positif yaitu sebanyak 25 orang $(65,8 \%)$.

2) Sebagian besar kelompok kasus dan kontrol berada pada status ekonomi rendah yaitu masing-masing sebanyak 24 orang $(63,2 \%)$. Semua kelompok kasus dan kontrol sudah mendapatkan imunisasi BCG setelah lahir. Mayoritas pada kelompok kasus terdapat perokok di dalam rumahnya yaitu sebanyak 31 orang 
$(81,6 \%)$, sedangkan kelompok kontrol yang terdapat perokok di dalam rumahnya sebanyak 20 orang $(52,6 \%)$.

3) Ada hubungan yang bermakna antara riwayat kontak TB dengan kejadian TB paru anak di BP4 Purwokerto setelah dilakukan analisis berstrata $(p=0,001$ dan OR yang dihasilkan sebesar 6,378 (Confidence Interval $(\mathrm{Cl})$ 95\%; 2,15118,918)).

4) Ada hubungan yang bermakna antara riwayat kontak TB dengan kejadian TB paru anak di BP4 Purwokerto dan tidak dipengaruhi oleh variabel status ekonomi, status imunisasi BCG dan keberadaan perokok di dalam rumah.

\section{b. Saran}

1. Bagi Masyarakat

Keluarga terutama orang tua anak perlu menjaga anak dari kontak langsung terhadap penderita TB dewasa BTA (+) dengan cara memisahkan anak sementara waktu jika terdapat keluarga dalam satu rumah yang menderita TB dan memberikan pengertian kepada penderita TB dewasa yang tinggal serumah untuk tidak meludah di sembarang tempat.

\section{Bagi BP4 Purwokerto}

Penemuan dan pengobatan penderita TB paru BTA positif secara dini untuk menurunkan angka penularan penyakit TB paru di masyarakat khususnya penularan pada anak-anak. Sebaiknya perlu adanya pemisahan ruang tunggu periksa antara pasien dewasa dan pasien anak guna mencegah kontak antara pasien anak dengan penderita TB dewasa.

\section{DAFTAR PUSTAKA}

1. Azzisman, Fauzi Z. A., Gusti A., Fridayenti, Andreas M., Zulkifli M., Harry, M. Yulis H., Elda N., Sri W., Rita E., Fifia C. Buku Tutor Hemomptisis. (On-line) http://eng.unri.ac.id. Diakses tanggal 6 Maret 2010. 2006.

2. Mustangin. Hubungan Pengetahuan dan Sikap Orang Tua TentangTuberkulosis Paru dengan Kejadian Tb Pada Anak di Balai Besar Kesehatan Paru Masyarakat (BBKPM) Surakarta. (On-line). www.anekajurnal.org. Diakses tanggal 11 Maret 2010. 2008.

3. FKUI. Buku Kuliah IImu Kesehatan Anak. FKUI .Jakarta. 1998.

4. Beaglehole, R. Dasar-dasar Epidemiologi. World Health Organization, Geneva. 1993.

5. Sinta, T. Artikel Kesehatan tentang Tuberkulosis Pada Anak. (On-line). www.masrafa.org. Diakses tanggal 6 Maret 2010. 2008.

6. Dudeng, D., Naning R. dan Pramono D. Faktor-Faktor yang Berhubungan dengan Kejadian Tuberkulosis pada Anak. Berita Kedokteran Masyarakat Vol. 22 No. 2. 2006.

7. Rosmayudi, O. Diagnosis dan Pengobatan Tuberkulosis pada Bayi dan Anak. (On-line). http://www.depkes.com. Diakses tanggal 7 Maret 2010. 2002.

8. Ajis, E., Mulyani, N.S., Dibyo P. Hubungan Antara Faktor-Faktor Eksternal dengan Kejadian Penyakit TB pada Balita di Kabupaten Kuantan Singingi, Provinsi Riau. (Online). www.ilib. ugm.ac.id/jurnal/download.php?datald.8314. Diakses tanggal 16 Juni 2010. 2009.

9. Crofton, J., Horne N., dan Miller F. Tuberkulosis Klinis. Widya Medika, Jakarta. 2002.

10. Murniasih, E dan Livana. Hubungan Pemberian Imunisasi BCG dengan Kejadian Tuberkulosis Paru pada Anak Balita di Balai Pengobatan Penyakit Paru-Paru Ambarawa Tahun 2007. Jurnal Kesehatan Surya Medika Yogyakarta. 2007. 
11. Wibowo, C., Winurti, Mewengkang, H. Kasus Kontak TB Paru di Poliklinik Paru Rumah Sakit Umum Pusat Manado. Majalah Kedokteran Indonesia Vol 54 No.3, Manado. 2004;54(3). 2004.

12. Fajriwan, Y. Pengaruh Asap Rokok Terhadap Saluran Napas. (Online).www.litbang.depkes.go.id. Diakses tanggal 8 Juni 2010. 1999. 
